\title{
PENGARUH TUMPANGSARI TERHADAP PERTUMBUHAN \\ DAN HASIL JAGUNG MANIS (Zea mays saccharatas Sturt.) \\ DAN PERKEBUNAN KARET (Hevea Brasiliensis)
}

\author{
INDRI OKTAVIANI \\ 1554201031 \\ Mahasiswa Fakultas Pertanian Prodi Agribisnis \\ UNIVERSITAS LANCANG KUNING \\ JL.YOS SUDARSO KM.8 RUMBAI PEKANBARU \\ Oktavianiindri952@gmail.com
}

\begin{abstract}
Artikel ini bertujuan untuk mengembangkan modul pengembangan kepribadian bagi mahasiswa agribisnis sebagai media dalam pelaksanaan layanan bimbingan pribadi di FAKULTAS PERTANIAN, UNIVERSITAS LANCANG KUNING PEKANBARU. Serta mengetahui pengaruh jagung manis yang ditumpangsarikan di area lahan karet, dan membahas kelebihan, kekurangan serta masalah yang di peroleh tanaman karet yang ditumpangsarikan dengan tanaman jagung manis. Untuk perkembangan pertumbuhan tanaman jagung manis di areal tanaman karet masih normal saja dibandingkan pertumbuhan dengan tanaman perkebunan lainnya. Karena sisitem perakaran tanaman karet akar tunggang dan akar tunggal. Sedangkan untuk tanaman karet itu sendiri akan mendapatkan keuntungan kesuburan tanah dari sisa pupuk tanaman jagung manis.
\end{abstract}

Kata kunci : Karet, Tumpang Sari, Jagung manis 


\section{PENDAHULUAN}

Banyaknya lahan perkebunan di indonesia membuat semakin berkurangnya lahan yang ada, ini disebabkan karena dalam sistem pananaman perkebunan diperlukan jarak tanam yang cukup lebar sehingga membuat lahan pertanian berkurang, dengan begitu kita dapat memanfaatkan lahan yang kosong tersebut sebagai nilai tambah tersendiri. Apabila tanaman karet di Tumpangsari kan dengan tanaman jagung manis maka dapat menyebabkan pertumbuhan tanaman karet terhambat di karenakan unsur hara terbagi dua antara penyerapan akar kedua tanaman tersebut. Tanaman karet akan terlindung dalam penyerapan sinar matahari maka sirkulasi udara diantara kedua tanaman tersebut menjadi lembab, dan timbullah penyakit jamur akar putih pada akar tanaman karet.

Tumpangsari antara tanaman karet dengan jagung manis bisa di tumpangsari akan tetapi jarak antara tanaman karet dengan tanaman jagung manis tersebut harus diatur jaraknya kurang lebih $80 \mathrm{~cm}-100 \mathrm{~cm}$ membentuk jalur agar persaingan penyerapan unsur hara keduanya akan terbagi secara optimal dan sirkulasi udara tidak terlalu lembab.

Tujuan dan keuntungan dari tumpangsari tanaman karet dengan jagung manis yaitu dapat memanfaatkan areal/ lahan yang kosong sehingga dapat meningkatkan produktivitas dan dapat menambah penghasilan, dapat membantu memperlambat pertumbuhan gulma di areal perkebunan karet, serta menambah kesuburan tanah dari sisa pupuk tanaman jagung manis. 


\section{TINJAUAN PUSTAKA}

Produksi jagung dapat ditingkatkan melalui peningkatan produktivitas dan perluasan pertanaman jagung. Peningkatan produksi jagung melalui peningkatan produktivitas relatif berjalan lambat. Oleh karena itu, perluasan pertanaman jagung merupakan pilihan cepat untuk peningkatan produksi jagung. Namun saat ini, perluasan pertanaman jagung yang ideal pada lahan sawah semakin terbatas karena alih fungsi lahan ke perkebunan. Menurut (Wijaksono dan Navastra, 2012) laju perubahan lahan pertanian tanaman pangan ke perkebunan mencapai $19.206 \mathrm{ha} / \mathrm{tahun}$.

(Surtinah, 2012) melaporkan varitas Bonanza yang ditanam di Pekanbaru menghasilkan kadar gula 14.82\% bila dipanen pada pukul 17:00 dan dipanen pada umur 65 hari setelah tanam. Pada penelitian yang lain (Surtinah, Pengujian Tiga Varietas Jagung Manis (Zea mays saccharata, Sturt) di Rumbai kota Pekanbaru. Jurnal Ilmiah Pertanian, Vol.1 (1) Edisi Khusus, 1-10., 2013) melaporkan bahwa varietas Bonanza adalah yang terbaik dibandingkan dua varietas lainnya, dengan berat tongkol tanpa kelobot $295 \mathrm{~g}$.

Panjang dan berat tongkol berkelobot berbeda tidak nyata yang dilaporkan dari suatu penelitian, fenomena ini bisa saja disebabkan oleh faktor vegetatif tanaman jagung manis dan faktor lingkungan yang diasumsikan homogen

Kendala pengembangan jagung di bawah tegakan tanaman karet adalah jenis tanah yang didominasi oleh Podsolik Merah Kuning dengan lapisan atas (top soil) sangat tipis antara 5-15 cm, miskin bahan organik, miskin hara $\mathrm{N}, \mathrm{P}, \mathrm{K}, \mathrm{Mg}, \mathrm{Ca}$, kemasaman tinggi ( $\mathrm{pH}$ rendah), karena kadar alumunium ( $\mathrm{Al})$ dan besi $(\mathrm{Fe})$ tinggi yang sangat menghambat pertumbuhan akar tanaman (Kuntyastuti dan Taufiq, 2008)

Kondisi tanah tempat tumbuh jagung manis sangat menentukan pertumbuhan dan produktivitas tanaman. Pada tanah PMK jagung manis dapat tumbuh dengan baik bila bahan organik tanah mencukupi (lidar dan surtinah, 2012). 


\section{HASIL DAN PEMBAHASAN}

Sistem cocok tanam polyculture merupakan suatu cara bercocok tanam dengan melibatkan lebih dari satu jenis tanaman dalam satu lahan pertanian. Sistem tanam polyculture ini lebih kita kenal dengan istilah tumpangsari. Tujuan dilakukannya tumpangsari ialah untuk mendapatkan produksi yang tinggi dan maksimal dengan lahan yang ada. Karena bercocok tanam dengan tumpangsari tanaman utama akan tetap tumbuh dengan semestinya dan tanaman tumpangsari juga akan tetap tumbuh tanpa mengganggu tanaman utama.

Perkembangan pertumbuhan tanaman jagung manis yang di tumpangsari kan di areal perkebunan karet masih terbilang normal tetapi ada juga kendalanya dikarenakan unsur haranya terbagi dua antara penyerapan akar kedua tanaman tersebut. Karena sistem perakaran tanaman karet akar tunggang dan akar tunggal, apabila tanaman jagung manis di tumpangsari dengan tanaman kelapa sawit untuk perkembangan tanaman jagung manis itu sendiri kurang normal karena pada tanaman kelapa sawit sistem perakarannya serabut, akar serabut tanaman kelapa sawit akan cepat menutup seluruh lapisan tanah.

Varietas jagung akan ditanam dalam gawangan karet dikarenakan jagung dengan sifat toleran pada $\mathrm{pH}$ rendah. Hal ini diperlukan karena umumnya karet ditanam pada tanah PMK yang miskin unsur hara dan tinggi $\mathrm{Al}$ dan Fe yang dapat menghambat pertumbuhan dan produksi tanaman. 


\section{KESIMPULAN}

Penanaman jagung di antara tanaman karet berpengaruh nyata terhadap peningkatan produktivitas lahan di antara tanaman karet, manfaat yang didapat dari tumpangsari antara tanaman karet dengan tanaman jagung manis sampai tanaman karet tersebut berumur $1-2$ tahun saja, dengan catatan apabila tanaman karet sudah berumur lebih kurang lima tahun kita harus hati-hati dengan akar serabut karet jangan sampai banyak yang terputus. Keuntungan ekonomi lainnya adalah kebun lebih terpelihara dan produktivitas tanaman karet meningkat. Secara ekonomi usaha tani jagung menguntungkan dan layak untuk dikembangkan sebagai tanaman sela karet pada masa TBM.

Kelemahan sistem usaha tani karet atau jagung secara monokultur adalah saat harga dunia turun, pendapatan petani turun drastis. Hal ini petani hanya mengandalkan pendapatan dari satu komoditas. Oleh karena itu, diperlukan pengembangan integrasi karet-jagung untuk meningkatkan produktivitas lahan dan pendapatan rumah tangga petani. 


\section{DAFTAR PUSTAKA}

Kuntyastuti dan Taufiq. (2008). Respon berbagai populasi jagung manis (Zea mays saccharata Sturt) terhadap pemberian pupuk urea. Jurnal Agroland Vol. 17 (2) : 138-143.

lidar dan surtinah. (2012). Respon tanaman jagung manis (Zea mays saccaharata Sturt) akibat pemberian Tiens Golden Harvest. Jurnal IImiah Pertanian Vol 8 (2):1-6.

Surtinah. (2013). Hubungan Pemangkas Organ Bagian Atas Tanaman jagung (Zea mays) dan Dosis Urea terhadap Pengisian Biji. Jurnal IImiah Pertanian, 27-35.

Surtinah. (2013). Pengujian Tiga Varietas Jagung Manis (Zea mays saccharata, Sturt) di Rumbai kota Pekanbaru. Jurnal Ilmiah Pertanian, Vol.1 (1) Edisi Khusus, 1-10.

Surtinah. (2012). Umur Panen yang tepat menetukan kandungan gula biji jagung manis (Zea mays saccharata, Sturt). Jurnal ilmiah Pertanian Vol.4 (2):1-6.

Wijaksono dan Navastra. (2012). Respon Tanaman Jagung Manis (Zea mays saccharat Sturt) Kultivar Hawaian Super Sweet pada berbagai Takaran pupuk Kalium. Jurnal Agrijati Vol. 6. 